\title{
Testing of Solar Power Plant Components off-Grid Systems and Engineering Economic Analysis at Cemara Island, Brebes Regency, Indonesia
}

\author{
Jaka Windarta $^{1,2^{*}}$, Ardhito Pratama ${ }^{1}$, Denis ${ }^{1}$, Agung Nugroho ${ }^{1}$ \\ ${ }^{I}$ Department of Electrical Engineering, Diponegoro University, Indonesia \\ ${ }^{2}$ Magister of Energy, Diponegoro University
}

*Corresponding Author: Jaka Windarta, Department of Electrical Engineering, Diponegoro University, Indonesia

\begin{abstract}
Indonesia is a country that is geographically located right in the equator and variously advantage and the wide for the use of solar energy. Indonesia has a relatively high radiation level, which is $4.80 \mathrm{kWh} /$ $m 2$ I day. Cemara Island is a tourist place but does not have electricity from PLN because access to its location is still difficult to reach. So from that chosen the planning system for the use of electrical energy using solar energy as the main electricity generation on the island. However, technical and economic analysis is needed so that the estimated weaknesses of the off-grid solar system can be estimated so as to reduce the risk of losses.

Testing of each component in the Solar Power Plant system also needs to be done to determine the condition and quality of the components to be used. Tests carried out include using solar panels, batteries, and inverters. Tests on solar panels are carried out within 2 days from 06.00AM - 18.00PM and data are taken per hour. The number of solar panel capacity is $8 \times 150 \mathrm{Wp}$, solar charge controller of 40 A, 4 units of battery with 100 Ah specifications, and 2000 Watt of an inverter. All DC voltage systems are working at $12 \mathrm{~V}$.

The economic analysis of the Cemara Island Solar Power Plant system with an initial investment of Rp 52,553,000, in scenario 1 uses interest at 6\%, then in scenario 2 without using interest. Through calculations by looking for the value of COE (Energy Cost), NPC (Net Present Cost) and BEP (Break Even Point), so that costs can be calculated by the manager with the number of 11 managers per month.
\end{abstract}

Keywords: Cemara Island, Solar Power Plant, Off-grid, Economic Analysis, Solar Power Plant Tests

\section{INTRODUCTION}

Indonesia is a country that is geographically located right on the equator and provides a variety of advantages and great potential in terms of solar energy utilization. The energy sector is one of the most important sectors in Indonesia because it is the basis for all other developments, especially by building electricity supply infrastructure to rural areas. The use of solar energy in Indonesia has a very good prospect, given that geographically as a tropical country, across the equator it has good solar energy potential. This is because the amount of solar radiation depends on the location of latitude, atmospheric conditions, and the position of the sun on the equator. Indonesia has a relatively high radiation level which is equal to $4.80 \mathrm{kWh} / \mathrm{m}^{2} /$ day. This is a big advantage for Indonesia in terms of the utilization and generation of solar energy into electricity. The Cemara Island Tourism Area, Sawojajar Village, Wanasari District in Brebes Regency is a new tourist attraction that is starting to be in great demand by domestic tourists from inside and outside Brebes Regency because of the natural beauty offered by it. Cemara Island is a small island measuring $0.12 \times 5$ kilometers to the north of Brebes Regency. This island offers the beauty of a charming panoramic beach with rows and cool pine trees. However, the absence of electrical energy is an obstacle for local residents to use optimal electricity services. The absence of facilities in the form of lighting installations and electrical installations has led to not optimal coastal tourism activities and the nature of the region. So with the 
Testing of Solar Power Plant Components off-Grid Systems and Engineering Economic Analysis at Cemara Island, Brebes Regency, Indonesia

absence of vacant land on the island that is not used, it can be optimized with the construction of the off-grid solar power system as a source of electrical energy for the residents of the island because State Electricity Company has not been able to access the location. The way solar cells work is by utilizing the theory of light as a particle as it is known that both visible and invisible light has two properties, which can be as waves and can be particles called photons, this discovery was first revealed by Einstein in 1905[8]. The use of solar panels as an alternative to generator sets and conventional electricity as electricity needs for residents who sell or live in the area. The writing of this final project aims to test the components of the off-grid PV system that has been planned and implemented as well as analyze the economy after the construction of the off-grid solar power system for residents in the Cemara Island Tourism Area.

\section{DISCUSSION}

In this research, there are two economic analysis scenarios that used to determine the effect of interest on the value of net present cost (NPC), cost of energy (COE) and break-even point (BEP) [9]. In addition, collecting data directly at the Solar Power Plant in the Cemara Island Tourism Area, Sawojajar District, Brebes Regency, and Central Java Province to find out the various parameters needed to analyze each component of the Solar Power Plant. There is some indicator that will be used to determine the quality of each components solar power plant on Cemara Island.

\subsection{Testing of Solar Panel System Components}

In this testing phase, data is collected directly at the Solar Power Plant on Cemara Island Tourism Area, Sawojajar District, Brebes Regency, Central Java Province to find out the various parameters needed to analyze each component of the solar power plant. Some of the data needed for this test are as follows:

Table1. Day-1 Solar Panel Test Data

\begin{tabular}{|c|c|c|c|c|}
\hline \multicolumn{5}{|c|}{ Day 1} \\
\hline Time & Irradiance $\left(\mathrm{W} / \mathrm{m}^{2}\right)$ & Suhu $\left({ }^{\circ} \mathrm{C}\right)$ & Voc (Volt) & Isc (A) \\
\hline 6.00 & 28.3 & 31 & 14 & 1.12 \\
\hline 7.00 & 140.3 & 32.7 & 23 & 4 \\
\hline 8.00 & 213 & 34.5 & 19 & 8.5 \\
\hline 9.00 & 624.2 & 39 & 37 & 10.2 \\
\hline 10.00 & 661 & 39.4 & 33 & 12.1 \\
\hline 11.00 & 928.4 & 40.5 & 39 & 11.4 \\
\hline 12.00 & 947.7 & 39 & 41 & 12 \\
\hline 13.00 & 1002 & 49 & 40 & 12 \\
\hline 14.00 & 629.9 & 51 & 36 & 12.2 \\
\hline 15.00 & 623 & 51.6 & 37 & 11.2 \\
\hline 16.00 & 221.8 & 32.7 & 14 & 12.2 \\
\hline 17.00 & 32 & 31.9 & 14 & 3.1 \\
\hline 18.00 & 25.9 & 31.8 & 13 & 1.9 \\
\hline
\end{tabular}

Table2. Day-2 Solar Panel Test Data

\begin{tabular}{|c|c|c|c|c|}
\hline \multicolumn{5}{|c|}{ Day 1 } \\
\hline Time & Irradiance $\left(\mathbf{W} / \mathbf{m}^{\mathbf{2}}\right)$ & Suhu $\left.\mathbf{(}^{\mathbf{0}} \mathbf{C}\right)$ & Voc (Volt) & Isc (A) \\
\hline 6.00 & 25.7 & 31.3 & 13 & 0.8 \\
\hline 7.00 & 140.3 & 34.6 & 18 & 8.5 \\
\hline 8.00 & 217.9 & 32.7 & 13 & 11.2 \\
\hline 9.00 & 221.8 & 49.2 & 19 & 12.2 \\
\hline 10.00 & 415 & 40.1 & 23 & 10.9 \\
\hline 11.00 & 422.7 & 51 & 34 & 12 \\
\hline 12.00 & 611.9 & 51.8 & 41 & 3.1 \\
\hline 13.00 & 217.9 & 34.8 & 31 & 1.9 \\
\hline 14.00 & 210.8 & 34.9 & 36 & 4 \\
\hline 15.00 & 135.2 & 31.9 & 37 & 0.8 \\
\hline 16.00 & 142.3 & 32.1 & 23 & 1.9 \\
\hline 17.00 & 32 & 31.8 & 14 & 13 \\
\hline 18.00 & 25.9 & 31.2 & & \\
\hline
\end{tabular}

International Journal of Research Studies in Electrical and Electronics Engineering (IJRSEEE) Page | 10 
Testing of Solar Power Plant Components off-Grid Systems and Engineering Economic Analysis at Cemara Island, Brebes Regency, Indonesia

Table3. Battery Test Data

\begin{tabular}{|c|c|c|c|c|c|}
\hline \multirow{2}{*}{ Baterai } & \multicolumn{5}{|c|}{ Data Pengukuran } \\
\cline { 2 - 6 } & $\begin{array}{c}\text { Vrating } \\
\text { (Volt) }\end{array}$ & $\begin{array}{c}\text { Cold Cranking Ampere } \\
\text { (CCA) }\end{array}$ & SOC (\%) & SOH (\%) & $\begin{array}{c}\text { Internal Resistance } \\
(\mathrm{mOhm})\end{array}$ \\
\hline Baterai 1 & 12.37 & 769 & 100 & 100 & 4.04 \\
\hline Baterai 2 & 12.30 & 896 & 100 & 100 & 3.47 \\
\hline Baterai 3 & 12.51 & 929 & 100 & 100 & 3.34 \\
\hline Baterai 4 & 12.74 & 692 & 94 & 100 & 4.49 \\
\hline
\end{tabular}

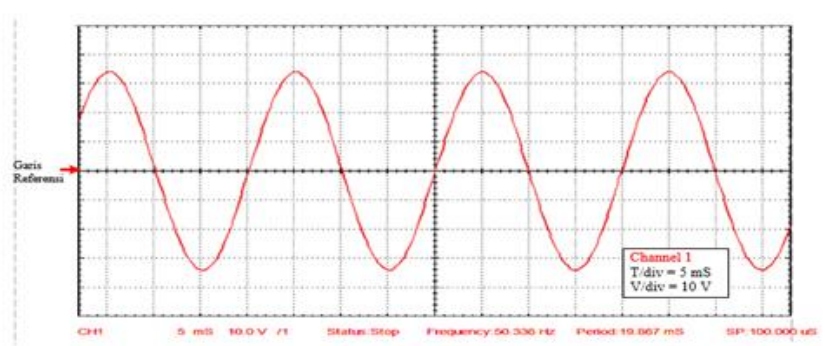

Figure1. Inverter Tests Data using Osilloscope

\subsection{Test Results on Solar Panels}

Tests on solar panel systems are carried out to analyze the efficiency of solar panels during irradiation conditions and the temperature changes per time. Simply put, the characteristics of this solar module are explained through a current curve to voltage (I-V Curve).

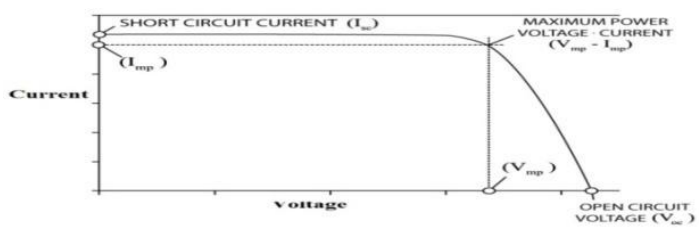

Figure2. Electrical Characteristics of a Solar Module Curve [2]

\section{Calculation of Input Power}

Due to the testing carried out in the condition that the solar panel is connected in series-parallel, so that the cross-sectional area of the solar panel becomes $7.87 \mathrm{~m} 2$. Calculation of solar panel input power at $6.00 \mathrm{a} . \mathrm{m}$. can be calculated based on the following equation:

Pin $=\mathrm{E} \times \mathrm{A}$

$=28.3 \times 7.87$

$=222.82$ watts

\section{Calculation of Fill Factor}

From the measurement results of the solar panel circuit at $06.00 \mathrm{WIB}$, the Voc value of $13 \mathrm{~V}$ and Isc $0.8 \mathrm{~A}$ is obtained, so that the calculated Vmp value and Imp can be calculated as follows:

Vmp count $=$ Voc Measure $\mathrm{x}($ Vmp nameplate $/$ Voc nameplate $)$

$=14 \times 18.6 / 22.4$

$=11,625 \mathrm{~V}$

Imp count $=$ Isc measure $\mathrm{x}(\operatorname{Imp}$ nameplate / Isc nameplate $)$

$=1.12 \times 0.94$

$=1.0528 \mathrm{~A}$

Then the Fill Factor value is obtained by calculating according to the following equation:

$\mathrm{FF}=(\mathrm{Vmp} \times \mathrm{Imp}) /($ Voc $\mathrm{x}$ Isc $)$

$=(11,625 \times 1.0528) /(14 \times 1.12)$

$=0.78$

3. Maximum power calculation

The maximum power value that can be released by solar panels at 06.00 can be calculated based on the following equation: 
Testing of Solar Power Plant Components off-Grid Systems and Engineering Economic Analysis at Cemara Island, Brebes Regency, Indonesia

$\mathrm{Pm}=$ Voc $\mathrm{x}$ Isc $\mathrm{x}$ FF

$=14 \times 1.12 \times 0.78$

$=12.27$ watts

4. Calculation of efficiency

Calculation of the efficiency of the actual solar panel data can be calculated using the following equation:

$\eta=\operatorname{Pm} / \operatorname{Pin} \times 100 \%$

$\eta=12,274 / 222,721 \times 100 \%$

$\eta=5.51 \%$

By using the same efficiency equation, the efficiency of the solar panel system is obtained every hour as in the following table:

Table4. Efficiency of Solar Panels Per Hour On Day-1

\begin{tabular}{|c|c|c|c|c|}
\hline Time & Irradiance $\left(\mathbf{W} / \mathbf{m}^{\mathbf{2}}\right)$ & Pin $($ Watt) & Pm (Watt) & $\boldsymbol{\eta}(\%)$ \\
\hline $6: 00$ & 28.3 & 222.8 & 12.2 & 5.5 \\
\hline $7: 00$ & 140.3 & 1104.1 & 72.0 & 6.5 \\
\hline $8: 00$ & 213 & 1676.3 & 126.4 & 7.5 \\
\hline $9: 00$ & 624.2 & 4912.4 & 295.4 & 6.0 \\
\hline $10: 00$ & 661 & 5202.0 & 312.5 & 6.0 \\
\hline $11: 00$ & 928.4 & 7306.5 & 348.0 & 4.7 \\
\hline $12: 00$ & 947.7 & 7458.3 & 385.1 & 5.1 \\
\hline $13: 00$ & 1002 & 7885.7 & 375.7 & 4.7 \\
\hline $14: 00$ & 629.9 & 4957.3 & 343.7 & 6.9 \\
\hline $15: 00$ & 623 & 4903.0 & 324.3 & 6.6 \\
\hline $16: 00$ & 221.8 & 1745.5 & 133.6 & 7.6 \\
\hline $17: 00$ & 32 & 251.8 & 33.9 & 13.4 \\
\hline $18: 00$ & 25.9 & 203.8 & 19.3 & 9.4 \\
\hline
\end{tabular}

Table5. Efficiency of Solar Panels Per Hour On Day-2

\begin{tabular}{|c|c|c|c|c|}
\hline Time & Irradiance $\left(\mathbf{W} / \mathbf{m}^{\mathbf{2}}\right)$ & Pin $($ Watt) & Pm (Watt) & $\boldsymbol{\eta}(\boldsymbol{\%})$ \\
\hline $6: 00$ & 25.7 & 202.2 & 8.1 & 4.0 \\
\hline $7: 00$ & 140 & 1101.8 & 56.3 & 5.1 \\
\hline $8: 00$ & 217.9 & 1714.8 & 86.4 & 5.0 \\
\hline $9: 00$ & 221.8 & 1745.5 & 166.5 & 9.5 \\
\hline $10: 00$ & 415 & 3266.0 & 219.6 & 6.7 \\
\hline $11: 00$ & 422.7 & 3326.6 & 290.0 & 7.9 \\
\hline $12: 00$ & 611.9 & 4815.6 & 385.1 & 5.8 \\
\hline $13: 00$ & 217.9 & 1714.8 & 99.4 & 5.2 \\
\hline $14: 00$ & 210.8 & 1658.9 & 87.3 & 5.1 \\
\hline $15: 00$ & 135.2 & 1064.0 & 55.0 & 6.4 \\
\hline $16: 00$ & 142.3 & 1119.9 & 72.0 & 3.4 \\
\hline $17: 00$ & 32 & 251.8 & 8.7 & 5.5 \\
\hline $18: 00$ & 25.9 & 203.8 & 11.3 & \\
\hline
\end{tabular}

The table shows the efficiency value of solar panels per hour on day 1, where the highest efficiency value at 17.00 is $13.4 \%$ and the lowest is at 11.00 and 13.00 which is $4.7 \%$. Whereas in the Table shows the efficiency of solar panels per hour on day 2, where the highest efficiency value at 09.00 is $9.5 \%$ and the lowest at 17.00 is $3.4 \%$. There are several factors that affect the output efficiency of solar cells, namely solar radiation, solar cell temperature, orientation of solar panels, the tilt angle of solar panels, and the influence of shadows (shading factor)[1]. Low-efficiency values due to external conditions such as the intensity of the sun and temperatures that are too high or too low.

\subsection{Battery Test Results}

Tests on the battery can determine the condition and quality of the battery to be used. To get the parameters of good condition or not the battery condition is carried out several tests, namely testing the Voltage rating, Cold Cranking Ampere, State of Charge, State of Health, and Internal Resistance 
Testing of Solar Power Plant Components off-Grid Systems and Engineering Economic Analysis at Cemara Island, Brebes Regency, Indonesia

Testing the battery individually is done directly before connecting to the solar panel so that the battery condition is known before the construction of the Solar Power Plant system.

\subsubsection{Voltage Rating Analysis on the Battery}

To analyze the voltage rating on the battery, it takes a comparison between the voltage obtained when testing the voltage rating on the nameplate as in the following table:

Table6. Nameplate of Energy cell 106RE Battery

\begin{tabular}{|c|c|}
\hline Specification & Score \\
\hline Voltage per unit & 12 VDC \\
\hline Maximum Charge Current & $30.0 \mathrm{~A}$ \\
\hline Float Charging Voltage & 13.5 to $13.8 \mathrm{VDC}$ \\
\hline Optimal Operating Temperature Range & 23 to $27^{\circ} \mathrm{C}$ \\
\hline
\end{tabular}

After looking at the voltage rating per unit on the battery nameplate, a battery analysis can be used in the following table:

Table7. Battery Rating Voltage Analysis

\begin{tabular}{|c|c|c|}
\hline Battery & Battery Analysis V rating > 12 V & Good \\
\hline Battery 1 & $12.37>12$ Volt & Good \\
\hline Battery 2 & $12.30>12$ Volt & Good \\
\hline Battery 3 & $12.51>12$ Volt & Good \\
\hline Battery 4 & $12.74>12$ Volt & . \\
\hline
\end{tabular}

Of all the batteries measured and checked, all batteries have a rating voltage rating greater than the battery nameplate rating voltage which is greater than $12 \mathrm{~V}$ so that the condition of all batteries is in good condition.

\subsubsection{Analysis of Cold Cranking Ampere on Battery}

The value of Cold Cranking Ampere (CCA) capability is obtained from 4 times the battery capacity, ie the value must be greater than 400 CCA because the battery used is 100Ah to say the condition of the battery is in good condition [4]. Based on the battery test data table, all batteries are in good condition with no damage at all. Factors that affect large CCA are usually found in the durability of the battery whether the battery has long been used or is still in a new condition. In this Solar Power Plant system, the battery used is all new batteries so there is no damage when a new battery is purchased and used.

\subsubsection{Analysis of State of Charge and State of Health on Battery}

Based on the results of the battery measurement data in the table, it can be analyzed State of Charge and State of Health on the battery. Based on the table, it can be seen the condition of the SOC on battery 1 , battery 2 , and battery 3 under conditions of $100 \%$ indicating that the battery is fully charged and battery 4 in the condition of $94 \%$ indicates the battery is almost full. For SOH conditions, due to the condition of the new battery, all batteries have a SOH value that is still above $90 \%$ (> 90\%) [5].

\subsubsection{Analysis of Internal Resistance on Battery}

Table8. Battery Internal Resistance Analysis

\begin{tabular}{|c|c|}
\hline Battery & Internal Resistance $(\mathrm{mOhm})$ \\
\hline Battery 1 & $4.04<5.5 \mathrm{Ohm}$ \\
\hline Battery 2 & $3.47<5.5 \mathrm{Ohm}$ \\
\hline Battery 3 & $3.34<5.5 \mathrm{Ohm}$ \\
\hline Battery 4 & $4.49<5.5 \mathrm{Ohm}$ \\
\hline
\end{tabular}

From the table, it can be seen that the internal resistance value of all batteries is below $5.5 \mathrm{Ohm}(<5.5$ $\mathrm{Ohm})$. This indicates that the condition of all batteries is in good condition. If the value of internal resistance is above $5.5 \mathrm{Ohm}(>5.5 \mathrm{Ohm})$, the battery will heat up faster and can damage the lifetime of the battery and will be damaged quickly [10].

\subsection{Inverter Test Result}

Take measurements using an oscilloscope at the inverter output to see the waveform generated from the inverter and the voltage. To compare the inverter output voltage values from the test results with the nameplate, data nameplate is needed as in the following table: 
Testing of Solar Power Plant Components off-Grid Systems and Engineering Economic Analysis at Cemara Island, Brebes Regency, Indonesia

Table9. Battery Internal Resistance Analysis

\begin{tabular}{|c|c|}
\hline Specification & Score \\
\hline Model & PSW 2000 \\
\hline Continuous Power & 2000 Watt \\
\hline Peak Power & 4000 Watt \\
\hline Output Voltage & 230 VAC \\
\hline Conversion Efficiency & Approx. 90\% \\
\hline Input Voltage & $12 / 24$ VDC \\
\hline
\end{tabular}

The inverter used is a Pure Sine Wave type inverter where the output from the inverter must be a sine wave. To calculate the amount of voltage generated by the inverter through the results of the oscilloscope in Figure 1, the calculation is carried out as follows:

Vpeak $=\mathrm{n} \times \mathrm{V} /$ div $\mathrm{x}$ probe scale

Where: $\mathrm{n}=$ number of boxes

$\mathrm{v} / \mathrm{div}=$ voltage per box

Then the calculation is obtained,

Vpeak $=3.2 \times 10 \mathrm{v} \times 10$

$=320 \mathrm{v}$

$\mathrm{Vrms}=\mathrm{Vp} / \sqrt{ } 2$

$=320 / \sqrt{ } 2$

$=226.27$ Volt

Based on the results of testing the inverter and calculation, the resulting voltage is 226.27 Volts. The comparison of the value of the calculated output voltage with the nameplate shows that the value in the calculation is almost in accordance with the voltage value on the nameplate. Differences in inverter output voltage values are tested by rating voltage on the nameplate due to the loss of power due to inverter losses and from converting the inverter. So it can be concluded that the inverter works well and the output voltage is a sign.

\subsection{Drop Voltage Test Results}

Testing for falling voltage is done by measuring the voltage at the source voltage (output of the inverter) and at the voltage at the final load. From the tests that have been done, we get the voltage as in the following table:

Table10. Drop Voltage Test Result

\begin{tabular}{|c|c|}
\hline Voltage Source & Tegangan (Volt) \\
\hline Voltage output of inverter & 225 \\
\hline Voltage on end of the line & 224 \\
\hline
\end{tabular}

In table 10, you can see the source voltage data at the final load voltage. Documentation of the test results is included in the attachment. Based on the data in table 10, it can be reviewed the falling voltage with the calculation of the voltage drop as follows:

$\mathrm{V}=$ (Initial Voltage-Final load voltage) / (Initial Voltage) $\mathrm{x} 100 \%$

$=(225-224) / 225 \times 100 \%=0.44 \%$

It can be stated that the falling voltage that occurs is in accordance with the existing standards, namely at PUIL Indonesia 2011 which states that the limit of the drop voltage permitted is $4 \%$.

\section{ECONOMY ANALYSIS}

The economic analysis carried out will be two scenarios, where the first scenario is a scenario with a source of capital originating from loan funds from the loan lending service provider, for example a bank with an interest rate of $6 \%$. The initial investment (C) used to build this SOLAR POWER PLANT system amounts to Rp. 52,553,000, maintenance costs (Mpw + Rpw) amounted to Rp. $5,479,196$ and with a yearly burden of $687 \mathrm{kWh}$.

\subsection{Scenario 1 with an Interest Rate of $6 \%$}

To obtain the Cost of Energy (COE), Net Present Cost (NPC) and Break Even Point (BEP) values, several calculation steps are carried out. In terms of the economy, the energy costs of a Solar Power Plant differ from the energy costs for conventional plants. This is because the energy costs of a Solar Power Plant are influenced by costs such as [3]: 
a. High initial costs (capital costs)

b. There is no charge for fuel

c. Low maintenance and operational costs

d. Replacement costs are low (especially for batteries only).

The calculation of the energy costs of a Solar Power Plant is obtained by life cycle costs (LCC), capital recovery factors (CRF) and annual production $\mathrm{kWh}$ of Solar Power Plants. Due to interest rates, the Capital Recovery Factor (CRF) calculation is carried out as follows:

$\mathrm{CRF}=\frac{\mathrm{i}(1+\mathrm{i})^{\mathrm{n}}}{(1+\mathrm{i})^{\mathrm{n}}-1}$

$=\frac{6 \%(1+6 \%)^{25}}{(1+6 \%)^{25}-1}=0.078$

Life cycle costs (LCC) are determined by initial investment costs (C), operational and maintenance costs (Mpw) and replacement costs (Rpw). So that the life cycle cost (LCC) of Solar Power Plnat in this study will be calculated as follows:

$\mathrm{LCC}[6]=(\mathrm{C} \times \mathrm{CRF} 25)+\mathrm{Mpw}+\mathrm{Rpw}$

$=($ IDR 52,553,000 x 0.078) + IDR 5,479,196

$=$ Rp. 9,590,245

Economic analysis in scenario 1, obtained the Cost of Energy (COE) value with the following equation [6] [7]:

$\mathrm{COE}=(\mathrm{LCC}) / \mathrm{kWH}$

$=($ Rp. 9,590,245) / 687

$=$ Rp. 13,960/ kWh

Annual income value is obtained by:

Revenue $=$ COE $x$ Load

$=$ Rp. $13,960 \times 687$

$=$ Rp. 9,590,245

The present total net cost (NPC) is the main economic output in the SOLAR POWER PLANT system. The first year NPC value of the Cemara Island SOLAR POWER PLANT system with an interest rate of $6 \%$ can be seen in the following calculation:

$\mathrm{NPC}=(((\mathrm{C} x \mathrm{CRF})+\mathrm{Mpw}+\mathrm{Rpw})) / \mathrm{CRF}=\mathrm{Rp} .52,722,053$

Then the value of NPC for 25 years is Rp 122,595,514. Breakeven point is a condition where the value of investment and income is at point 0 , or it can be said that it is in a condition not experiencing a loss and not experiencing a profit. Average annual operating and maintenance costs for a period of 25 years and an interest rate of $6 \%$ can be searched in the following ways:

$\mathrm{O} \& \mathrm{M}$ Average $=(\mathrm{NPC}-$ Initial Investment Cost $) / 25$

$=($ IDR $122,595,514-$ IDR 52,553,000) $/ 25$

$=\operatorname{Rp} 2,801,700$

By knowing the average operational and maintenance costs, BEP values can be calculated with the following parameters:

Fixed Cost $\quad=$ IDR 52,553,000

COE $\quad=$ Rp. $13,960 / \mathrm{kWh}$

Variable Cost $=\operatorname{Rp} 2,801,700 / 687=\operatorname{Rp} 4,078$

Then we get a BEP value of:

$\mathrm{BEP}$ in $\mathrm{KwH}=52,553,000 /(13,960-4,078)=6,434 \mathrm{kWh}$

Then the cost to be paid by the people of Cemara island for each shop in a month in scenario 1 is as big as:

Cost per month $=($ electricity sales revenue $) /(11$ stalls $\times 12$ months $)$

International Journal of Research Studies in Electrical and Electronics Engineering (IJRSEEE) Page | 15 
Testing of Solar Power Plant Components off-Grid Systems and Engineering Economic Analysis at Cemara Island, Brebes Regency, Indonesia

Cost per month $=($ Rp. 9,590,245) $/ 132$

$=$ Rp. 72,653

So per shop is required to pay Rp. 72,653 per year

\subsection{Scenario 2 without interest rates}

The NPC value in scenario 2 is not affected by the value of interest rates, so the value of the NPC in the first year is only the sum of the initial investment costs and maintenance costs (Rpw), as well as the following year until the project year 25 , can be seen in the following calculation:

$\mathrm{NPC}_{1^{-}}=\mathrm{C}+$ Biaya $0 \& M \& R=\operatorname{Rp} 52,553,000+\mathrm{Rp} 5,479.196=\operatorname{Rp} 58,032,196$

Cost of Energy in scenario 2, has a difference with the scenario 1where in scenario 2 there is no interest rate factor that affects the value of COE. Then, the value of COE can be calculated using the following equation:

$$
\begin{aligned}
& \mathrm{COE}=\frac{\mathrm{NPC}_{25}}{\mathrm{kWh} 25} \\
& =\frac{\operatorname{Rp} 189,532,900}{687 \times 25} \\
& =\frac{\operatorname{Rp} 189,532,900}{17175}
\end{aligned}
$$

$=\operatorname{Rp} 11,035$

By knowing the value of COE, it can be seen that the income earned within a year by doing COE multiplication with the total electrical energy used in a year. Then from the multiplication obtained annual income as follows:

Income $=\mathrm{COE} \times$ Expenses per year

$=$ Rp. $11,035 \times 687$

$=\operatorname{Rp} 7,581,316$

Average annual operating and maintenance costs for a period of 25 years and an interest rate of $6 \%$ can be searched in the following ways:

Average operational and maintenance costs, BEP values can be calculated with the following parameters:

O\&M Average $=(\mathrm{NPC}-\mathrm{C}) / 25$

$=(\operatorname{Rp} 189,532,900-\operatorname{Rp} 52,553,000) / 25$

$=\operatorname{Rp} 5,479,196$

Fixed Cost $=$ IDR 52,553,000

$\mathrm{COE}=\mathrm{Rp} .11,035$

Variable Cost $=\operatorname{Rp~5,479,196/~} 687=\operatorname{Rp} 7,976$

Then we get a BEP value of:

$\mathrm{BEP}$ in $\mathrm{KwH}=52,553,000 /(11,035-7,976)=17,175 \mathrm{kWh}$

From these calculations, it can be seen to get a capital turnover or BEP, so the sale of power is needed at $17,175 \mathrm{kWh}$. The cost to be paid by the Cemara Island stall manager is divided equally by each stall, with annual revenue costs of $\mathrm{Rp} 2,695,587$, the calculation of the cost of each stall on Cemara Island can be calculated as follows:

Cost per month $=($ electricity sales $/$ month $) /(11$ stalls $x 12$ months $)$

Cost per month $=($ Rp. 7,581,316) $/ 132$

$=$ Rp. 57,434

Then the cost to be paid by the people of Cemara island for each shop in a month in scenario 2 is Rp. 57,434

International Journal of Research Studies in Electrical and Electronics Engineering (IJRSEEE) Page | 16 


\section{SUMMARY}

1. From the results of testing on the components of the Solar Power Plant installed in the Cemara Island Tourism Area, it was found that the efficiency of solar panels is still relatively small where efficiency should be around $12-14 \%$, and the efficiency obtained from testing is only around $3 \%-9 \%$ only. This of course affects the power that can be generated by SOLAR POWER PLANT per day. Tests that have been done on batteries and inverters can be said that both components are in good condition.

2. To find out the quality and condition of the battery can be done by testing the battery by testing the value of the rating voltage, the value of Cold Cranking Ampere, State of Charge, State of Health and Internal Resistance of the battery.

3. Inverter test results that have been tested using Oscilloscope, show inverter waveforms in the form of a pure sine wave with 226.27 Volt voltages, when compared with the voltage rating on the inverter nameplate, a voltage difference occurs where the lost power can occur due to loss inverter losses and from inverter conversion.

4. The value of the source voltage is 225 Volt and the final load voltage value is 22 Volts, so it can be obtained the drop voltage that occurs in the SOLAR POWER PLANT system is $0.44 \%$. The resulting stress drop is difficult according to the standards in PUIL 2011 with a permissible limit of $4 \%$.

5. The economic analysis conducted with 2 scenarios is obtained in scenario 1, the Cost of Energy value is Rp. 13,960 / kWh, Net Present Cost (NPC) is Rp. 122,595,514, Break Even Point (BEP) is 6,434 kWh. From the results of the calculation of BEP, it was found that the turning point in the 12th year. From the results of the COE, NPC and BEP calculations, the monthly fee to be paid per stall is Rp. 72,653.

6. In economic analysis scenario 2, the Cost of Energy (COE) value is Rp. 11,035 / kWh, the Net Present Cost (NPC) is Rp. 189,532,900, Break Even Point (BEP) is 17,175 kWh. From the results of the calculation of the BEP, the turnover point is right in the 25th year. From the results of the COE, NPC and BEP calculations, the monthly fee to be paid per stall is Rp. 57.43 .

\section{REFERENCES}

[1] King, Boyson, \& Kratochvil, Analysis of Factors Influencing The Annual Energy Production of Photovoltaic Systems, IEEE, 2002.

[2] ABB, Technical Application Papers N0.10 Photovoltaic Plants, Bergamo Italy, 2008.

[3] A. E. A. Nafeh, "Design and Economic Analysis of a Stand-Alone PV System to Electrify a Remote Area Household in Egypt," Open Renew. Energy J., vol. 2, pp. 33-37, 2009.

[4] Battery and Electrical System Tester User's Manual, PlusQuip Co., Melbourne, AU, 2000.

[5] He, Lei, Bingjun Xiao, and Yiyu Shi. “A Universal State-of-Charge Algorithm for Batteries.” 47th IEEE Design Automation Conference "DAC '10”, 2010.

[6] M. Kolhe, S. Kolhe, and J. C. Joshi, "Economic viability of stand-alone solar photovoltaic system in comparison with diesel-powered system for India," Energy Econ., vol. 24, pp. 155-165, 2002.

[7] B. A. A. Abdel-Ghani, "Techno-Economic Evaluation Of Electrification Of Small Villages In Palestine By Centralized And Decentralized Pv System," An-Najah Natl. Univ., 2008

[8] Klaus Jäger, Olindo Isabella amd Arno H.M. Smets, "Solar Energy Fundamentals, Technology and Systems", 1st ed., Deift University of Technology, Netherlands, 2014.

[9] Tung Au, Thomas P. AU, Engineering Economics For Capital Investment Analysis, 2nd edition. New Jersey, America: PRENTICE HALL 2005.

[10] D. Ansean, V.M. Garcia, C. Blanco, "DC internal resistance during charge: analysis and study on LiFePO4 batteries" EVS27 International Battery, Hybrid and Fuel Cell Electric Vehicle Symposium, November 2013.

Citation: Jaka Windarta, et.al. (2019). "Testing of Solar Power Plant Components off-Grid Systems and Engineering Economic Analysis at Cemara Island, Brebes Regency, Indonesia”. International Journal of Research Studies in Electrical and Electronics Engineering (IJRSEEE), 5(2), pp 9-17. DOI: http://dx.doi. org/10.20431/2454-9436.0502002

Copyright: () 2019 Authors. This is an open-access article distributed under the terms of the Creative Commons Attribution License, which permits unrestricted use, distribution, and reproduction in any medium, provided the original author and source are credited. 